Web Jurnal:

http://ejournal.kemenperin.go.id/jli

\title{
Pengaruh pemakaian jahe emprit dan jahe merah terhadap karakteristik fisik, total fenol, dan kandungan gingerol, shogaol ting-ting jahe (Zingiber officinale)
}

\section{The used effect of yellow ginger and red ginger on physical characteristic, total phenol, and the content of gingerol, shogaol of ginger ting-ting (Zingiber officinale)}

\author{
F Firdausni*, K Kamsina \\ Balai Riset dan Standardisasi Industri Padang \\ Jl. Raya LIK No.23 Ulu Gadut Padang, Indonesia \\ * e-mail: firdausni85@gmail.com
}

\begin{tabular}{l}
\hline INFO ARTIKEL \\
\hline Sejarah artikel: \\
Diterima: \\
8 November 2018 \\
Direvisi: \\
10 Desember 2018 \\
Diterbitkan: \\
28 Desember 2018 \\
\hline
\end{tabular}

\begin{tabular}{l}
\hline Kata kunci: \\
jahe; \\
gingerol; \\
fenol; \\
ting-ting jahe
\end{tabular}

\begin{tabular}{l}
\hline Keywords: \\
ginger; \\
gingerol; \\
phenol; \\
ginger ting-ting
\end{tabular}

\begin{abstract}
ABSTRAK
Pemanfaatan jahe menjadi suatu produk alternatif yang mempunyai nilai tambah salah satunya adalah makanan ringan ting-ting jahe. Produk ini merupakan pangan fungsional yang berkhasiat obat. Penelitian bertujuan untuk mengetahui pengaruh jenis jahe dan penambahan jahe terhadap karakteristik fisik, total fenol, kandungan utama jahe gingerol dan shogaol ting-ting jahe. Penelitian dilakukan dengan menggunakan jahe emprit dan jahe merah dengan persentase penambahan terhadap bahan 10\%, 20\% dan 30\%. Hasil penelitian menunjukkan bahwa pemakaian jenis jahe memberikan pengaruh terhadap total fenol, gingerol dan shogaol ting-ting jahe. Perlakuan optimal didapatkan pada tingting jahe emprit dengan penambahan 30\% dengan total fenol 1,66\%, gingerol (6,8 dan 10 gingerol) berturut turut $0,172 \mathrm{mg} / \mathrm{g} ; 0,163 \mathrm{mg} / \mathrm{g} ; 0,275 \mathrm{mg} / \mathrm{g}$, dan 6 shogaol 0,150 $\mathrm{mg} / \mathrm{g}$. Penilaian organoleptik tingkat kesukaan panelis terbaik diperoleh pada perlakuan ting-ting jahe merah $20 \%$ dengan rasa, aroma dan tekstur 3,$90 ; 3,75 ; 3,45$ yaitu disukai.
\end{abstract}

\begin{abstract}
An alternative product from ginger that has an added value is by making it as a snack food called ginger ting-ting. This product is a functional food which has a medicinal properties. The study was aimed to determine the effect of ginger type and the addition of ginger to the physical characteristics, total phenol, the main content of ginger gingerol and shogaol of ginger ting-ting. The study was carried out using yellow ginger and red ginger with the percentage of addition to the ingredients of 10\%, 20\%, and 30\%. The results showed that the use of the ginger type affected the total phenol, gingerol, and shogaol of ginger ting-ting. The optimal treatment was obtained in yellow ginger tingting at the addition $30 \%$ with total phenol 1.66\%, gingerol (6, 8, and 10 gingerol) 0.172 $\mathrm{mg} / \mathrm{g} ; 0.163 \mathrm{mg} / \mathrm{g} ; 0.275 \mathrm{mg} / \mathrm{g}$ respectively, and 6 shogaol $0.150 \mathrm{mg} / \mathrm{g}$. Organoleptic assessment of the best panelist preference level was obtained at the treatment $20 \%$ red ginger ting-ting with the taste, flavor, and texture were preferred with value 3.90; 3.75; 3.45 recpectively.
\end{abstract}

(C) 2018 Penulis. Dipublikasikan oleh Baristand Industri Padang. Akses terbuka dibawah lisensi CC BY-NC-SA

\section{Pendahuluan}

Tanaman jahe (Zingiber officinale) mudah tumbuh dan telah banyak dibudidayakan di Indonesia. Jahe merupakan rimpang tanaman jahe mempunyai rasa, aroma yang khas, dan enak sehingga disukai banyak orang. Oleh karena itu, komoditi ini sangat populer dikalangan masyarakat. Jahe dapat digunakan sebagai bumbu untuk masakan, bahan baku minuman penghangat tubuh, dan obat-obatan. Dalam bidang makanan/ minuman, jahe dapat dibuat wedang jahe, sekoteng, manisan jahe, wedang kopi jahe, dan sebagainya. Pengolahan jahe diantaranya sebagai jahe instan (Firdausni et al., 2017) makanan ringan, asinan 
dan manisan jahe yang tersedia dalam bentuk sudah dikemas dengan baik sehingga menjadi produk dengan nilai komersial tinggi dan berpotensi sebagai produk ekspor.

Dibalik rasanya yang pedas dan menghangatkan, peranannya sebagai obat berhubungan erat dengan fungsinya sebagai antioksidan. Hal ini sangat erat kaitannya dengan peranan antioksidan dalam memelihara dan menjaga kesehatan karena mampu menangkap molekul radikal bebas dan spesies oksigen reaktif sehingga menghambat reaksi oksidatif yang merupakan penyebab penyakitpenyakit degeneratif seperti penyakit jantung, kanker, katarak, disfungsi otak dan arthritis. Jahe mengandung sekurangnya 19 komponen bio-aktif yang berguna bagi tubuh. Komponen yang paling utama adalah gingerol yang bersifat antikoagulan, yaitu mencegah pengumpalan darah dan melancarkan aliran darah sehingga dapat mencegah penyakit stroke, jantung dan penyakit degeneratif lainnya (Yeh et al., 2014). Oleoresin merupakan salah satu senyawa non volatil yang mengandung minyak atsiri $15-35 \%$ yang diekstraksi dari bubuk jahe. Semakin tinggi kandungan oleoresin maka semakin pedas rasa ekstrak jahe yang dihasilkan dan semakin tinggi efek antioksidannya.

Penerapan teknologi pengolahan jahe sangat berperan dalam program penganekaragaman (diversifikasi) makanan yang dapat diterapkan pada industri kecil menengah. Ting-ting jahe adalah salah satu makanan ringan olahan jahe yang disukai dan sering ditemui, dibuat dengan bahan baku jahe ditambah dengan bahan penolong lainnya seperti kelapa, gula, kacang, dan wijen. Makanan ting-ting jahe ini dapat kita temui di super market maupun di pasar rakyat. Pada saat menjelang hari Raya Idul Fitri banyak peminat yang membeli produk ini.

Ting-ting jahe merupakan pangan fungsional yaitu produk pangan yang memberikan keuntungan terhadap kesehatan. Pangan fungsional dapat mencegah atau mengobati penyakit (Erniati et al., 2016). Beberapa macam penyakit yang disebabkan oleh oksidan seperti kardiovaskular, kanker, dan katarak dapat dihambat oleh antioksidan (Stoilova et al., 2007a). Kebanyakan efek membahayakan yang potensial dari oksidan berasal dari spesies oksigen reaktif (ROS) seperti radikal bebas, yang dapat berasal dari polusi, debu, maupun diproduksi secara kontinyu sebagai konsekuensi dari metabolisme normal. Antioksidan merupakan senyawa berberat molekul kecil yang dapat bereaksi dengan oksidan sehingga reaksi oksidasi yang merusak biomolekul dapat dihambat (Asimi et al., 2013).

Pangan fungsional akan semakin berkembang dimasa datang. Hal ini erat kaitannya dengan meningkatkan imunitas tubuh, menghambat penuaan, meningkatkan kebugaran, kecantikan dan penampilan. Penelitian yang dilakukan oleh (Stoilova et al., 2007b) menyatakan bahwa ekstrak air jahe dari jahe bubuk mempunyai aktivitas antioksidan terhadap asam linoleat karena kemampuannya dalam menghambat pembentukan malonaldehida. Jenis antioksidan fenolik pada jahe diantaranya gingerol, shogaol dan zingeron. Adanya aktivitas antioksidan ekstrak air jahe memungkinkan penggunaan ekstrak air jahe sebagai pangan fungsional dan diolah menjadi produk seperti jahe instan dengan menggunakan gula pasir : gula aren 3:1 dan penstabil cmc $1 \%$ menghasilkan $6,8,10$ gingerol berturut turut yaitu $1,240 \mathrm{mg} / \mathrm{g} ; 0,045 \mathrm{mg} / \mathrm{g} ; 0,070$ $\mathrm{mg} / \mathrm{g}$ (Firdausni et al., 2017).

Penelitian ini bertujuan untuk mengetahui karakteristik fisik, sensori, total fenol, kandungan gingerol dan shogaol ting-ting jahe dengan variasi jenis jahe (jahe emprit dan jahe merah).

\section{Metode}

Bahan baku berupa jahe emprit dan jahe merah berasal dari Pasar Raya Padang. Bahan penolong yang digunakan yaitu gula pasir, gula aren, kelapa, kacang tanah, wijen, minyak goreng dan bahan yang digunakan untuk analisis aquades, metanol, larutan 2,2 diphenyl-1picrylhydrazyl hydrate (DPPH) 0,0001 g, $\left(\mathrm{NH}_{4}\right) \mathrm{HPO}$ $10 \%, \mathrm{HCl} 25 \%, \mathrm{Na} \mathrm{OH} 30 \%$, asam linoleat, TCA asam trikloroasetat, buffer fosfat, $\mathrm{FeCl} 2$, ammonium tiosianat, Folin Ciocalteau serta kemasan.

Peralatan yang digunakan antara lain timbangan, crusher (penghancur), pisau, pengaduk, peniris, dan alat-alat pengujian, labu ukur, termometer, penangas air, neraca analitik, spektrofotometer absorbsi atom (AAS), timbangan analitik, pH meter, kertas saring, gelas ukur, erlenmeyer, pipet spektrofotometer UV-vis.

\subsection{Metoda penelitian \\ 2.1.1. Pelaksanan penelitian}

Penelitian pembuatan ting ting jahe dilakukan dengan perlakuan jenis jahe yaitu jahe emprit dan jahe merah dan konsentrasi penambahan jahe $(10 \%, 20 \%$ dan $30 \%)$, sehingga menjadi 6(enam) perlakuan dengan 3 (tiga) kali ulangan.

Jahe yang digunakan didapatkan di kota Padang, dilakukan sortasi jahe sesuai SNI 01-7087-2005 untuk jahe segar, tidak ada rimpang bertunas, kenampakan irisan melintang cerah, bentuk rimpang utuh.

\subsubsection{Persiapan bahan baku}

Jahe segar (jahe emprit dan jahe merah) yang telah disortir dibersihkan dengan menggunakan air bersih atau air mengalir, selanjutnya dipotong potong. Dihaluskan atau dihancurkan dengan menggunakan blender.

\subsubsection{Pembuatan ting-ting jahe}

Pembuatan ting ting jahe dengan cara pemanasan dan pengadukan semua bahan secara bertahap seperti uraian berikut ini.

a. Kelapa dengan ketuaan sedang diparut dan diambil yang bagian putihnya.

b. Kacang tanah dengan kualitas baik digongseng dan dicincang, begitu juga dengan wijen digongseng dengan panas sedang, sehingga warna kuning kecoklatan.

c. Serundeng dibuat dengan cara mencampurkan kelapa parut dan jahe yang sudah dihaluskan. 
d. Gula pasir dimasukkan ke dalam wajan lalu panaskan dan diaduk-aduk sehingga terbentuk karamel gula dengan aroma yang khas, ditambahkan adonan serundeng (campuran jahe, kelapa), kacang tanah, dan wijen diaduk homogen sehingga larutan gula melapisi seluruh permukaan serundeng.

e. Adonan dikeluarkan, selanjutnya dicetak yang terlebih dahulu dilapisi daun pisang, dipipihkan dengan penggilas bulat dan dipotong-potong,

f. Kemudian digulung atau ditekuk membentuk kerucut, pengerjaan ini dilakukan pada saat masih panas.

g. Ting-ting jahe siap dikemas dengan menggunakan plastik tebal tertutup.

h. Dalam keadaan panas lalu dipindahkan ke cetakan yang terlebih dahulu dilapisi daun pisang, dipipihkan dengan penggilas bulat dan dipotong-potong, biasanya dengan menggunakan gunting membentuk empat persegi, jajaran genjang.

i. Kemudian digulung atau ditekuk membentuk kerucut, pengerjaan ini dilakukan pada saat masih panas.

j. Ting-ting jahe siap dikemas dengan menggunakan plastik tebal tertutup.

\subsection{Pengujian dan analisis}

\subsubsection{Penentuan kadar fenol total}

Kadar fenol total ditentukan dengan metode Folin Ciocalteu menggunakan asam galat sebagai standar. Sampel $50 \mu \mathrm{l}$ ditambah larutan Folin-ciocalteu $250 \mu \mathrm{l}$, kemudian didiamkan 1 menit dan ditambahkan $750 \mu \mathrm{l}$ $\mathrm{NaCO}_{3} 20 \%$, selanjutnya divortek, dan ditambah akuades sampai volume $5 \mathrm{ml}$. Setelah diinkubasi 5 menit pada suhu kamar, absorbansi ditera pada $\lambda 760 \mathrm{~nm}$. Asam galat digunakan sebagai standar dan kurva kalibrasi dibuat dengan asam galat 31,875 sampai $510 \mathrm{mg} / \mathrm{L}$ dengan $\mathrm{r}=$ 0,99. Hasil perhitungan fenol total adalah mg Ekivalen Asam Galat (EAG) per g ekstrak kering. (Mukhtar and Ahmad, 2000).

\subsubsection{Penentuan kadar gingerol dan shogaol}

Pengujian komposisi kandungan (6)-, (8)-, (10)gingerol dan (6)-shogaol pada ting-ting jahe (jahe emprit dan jahe merah) dilakukan dengan menggunakan metode LC-PDA (liquid chromatography - photodiode array detection). Simplisia jahe diekstrak dengan sonikasi menggunakan metanol pada suhu ruang. Ekstrak kemudian dianalisis dengan HPLC (Shim pack ODS VP C 18 150Lx4.6) panjang gelombang $280 \mathrm{~nm}$ dan laju alir fase gerak $1 \mathrm{ml} /$ menit (Dugasani et al., 2010).

\subsubsection{Uji hedonik/tingkat kesukaan}

Uji hedonik atau tingkat kesukaan dilakukan dengan pengambilan data dari panelis. Panelis memberikan tanggapan terhadap produk tentang kesukaan atau ketidaksukaan. Pada pengamatan suka dengan skala hedonik amat sangat suka, sangat suka, suka, agak suka dan tidak suka.

Pengujian hedonik dilakukan pada panelis terlatih dengan menyajikan ke enam jenis ting-ting jahe. Atribut-atribut yang diamati antara lain rasa, aroma, tekstur. Sebanyak 20 orang panelis memberikan penilaian terhadap masing-masing sampel. Skala penilaian yang digunakan dengan nilai yaitu 5 sampai 1 (sangat suka, suka, biasa/agak suka, kurang suka, dan tidak suka).

\section{Hasil dan pembahasan}

\subsection{Pengamatan terhadap bahan baku jahe dan produk ting-ting jahe}

Pengamatan dilakukan terhadap bahan baku jahe yang digunakan dan pengamatan fisik ting-ting yang dihasilkan dari perlakuan jahe emprit dan jahe merah dengan penambahan 10\%, 20\% dan 30\% ( Tabel 1).

Tabel 1

Hasil pengamatan dan karakteristik jahe dan ting-ting jahe

\begin{tabular}{lll}
\hline Karakteristik & Jahe emprit & Jahe merah \\
\hline $\begin{array}{l}\text { Kadar air jahe segar } \\
\text { (\%bb) }\end{array}$ & 87,14 & 85,38 \\
$\begin{array}{l}\text { Kadar air ting-ting } \\
\text { (\%bb) }\end{array}$ & 2,77 & 2,13 \\
$\begin{array}{l}\text { Aroma } \\
\text { Warna }\end{array}$ & $\begin{array}{l}\text { Khas jahe } \\
\text { Kuning } \\
\text { kecoklatan }\end{array}$ & $\begin{array}{l}\text { Khas jahe } \\
\text { Kuning } \\
\text { kecoklatan }\end{array}$ \\
Gambar produk & & \\
\hline
\end{tabular}

Hasil analisis kadar air jahe segar didapatkan bahwa jahe emprit dengan kadar air sebesar $87,14 \%$ lebih tinggi dari jahe merah $85,38 \%$. Setelah diolah menjadi tingting jahe didapatkan kadar air 2,77\% $\pm 0,13$ menggunakan jahe emprit dan 2,13\% $\pm 0,21$ menggunakan jahe merah. Kadar air sangat berpengaruh kepada mutu dan daya simpan produk.

\subsection{Total fenol}

Hasil analisis fenolat total ting-ting jahe dengan menggunakan jahe emprit dan jahe merah (Tabel 2) dapat dilihat bahwa jenis jahe memberikan total fenol berbeda dimana jahe emprit mempunyai kadar total fenol lebih tinggi dari jahe merah. Senyawa fenol merupakan sumber aktioksidan yang efektif penekan radikal bebas, pengkelat ion-ion logam. Senyawa fenolik merupakan senyawa kimia yang mempunyai satu buah cincin aromatik yang mengandung satu atau lebih fungsi hidroksi (Srinivasan, 2017) Kandungan total fenol dipengaruhi oleh ketersediaan senyawa fenol suatu bahan (Putri, 2011). Ting-ting jahe dengan pemakaian jahe emprit mempunyai rata-rata total fenol lebih tinggi dari jahe merah. Pengaruh presentase penambahan jahe seiring dengan peningkatan nilai total fenol dimana semakin meningkat jahe yang ditambahkan maka semakin tinggi nilai total fenolnya. 
Tabel 2

Kandungan total fenol ting-ting jahe menggunakan jahe emprit dan jahe merah

\begin{tabular}{ll}
\hline Perlakuan & Total fenol (\%) \\
\hline Jahe emprit $10 \%$ & 1,05 \\
Jahe emprit $20 \%$ & 1,64 \\
Jahe emprit $30 \%$ & 1,66 \\
Jahe merah $10 \%$ & 1,21 \\
Jahe merah 20\% & 1,24 \\
Jahe merah 30\% & 1,34 \\
\hline
\end{tabular}

Total fenol merupakan komponen penting terkait dengan sifat antibakteri. Penambahan jahe emprit 30\% dengan total fenol $1,66 \%$, sedangkan pada jahe merah $30 \%$ mempunyai total fenol $1,34 \%$. Jenis bahan mempengaruhi total fenol. Pada pembuatan jahe instan dengan penambahan cassiavera didapatkan total fenol 26,51 ppm (Firdausni et al., 2011). Total fenol pada ekstrak gambir dengan pelarut etil asetat sebesar 80,3\% (Pambayun et al., 2007). Penelitian pengukuran total fenol dan kapasitas antioksidan pada daun tanaman obat Indonesia didapatkan total fenol sirih $1070 \mathrm{mg} / 100 \mathrm{ml}$, mengkudu $60,34 \mathrm{mg} / 100 \mathrm{ml}$ dan mahkota dewa sebesar $150 \mathrm{mg} / 100 \mathrm{ml}$.

\subsection{Gingerol dan shogaol}

Gingerol dengan rumus kimia $\mathrm{C}_{17} \mathrm{H}_{26} \mathrm{O}_{4}$ merupakan komponen kimia utama jahe. Gingerol secara kimiawi tidak stabil pada suhu yang tinggi dan berubah menjadi shogaol. Gingerol jahe yang terdiri dari 6,8 dan 10 gingerol. Penambahan jahe merah dan jahe emprit pada pembuatan ting-ting jahe memberikan gingerol yang berbeda seperti pada Gambar 1, 2, dan 3 .

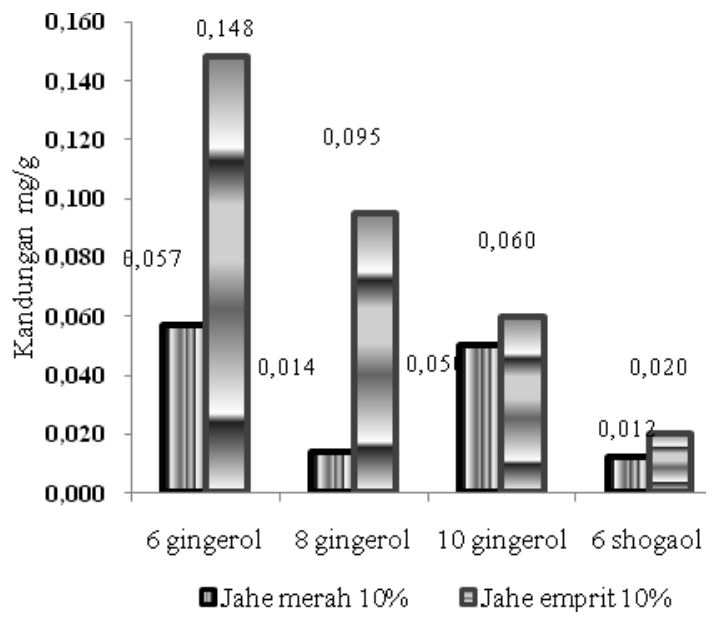

Gambar 1. Kadar Gingerol (6, 8, 10 gingerol) dan 6 Shogaol ting-ting jahe pada penambahan jahe $10 \%$.

Gingerol jahe yang terdiri dari 6, 8 dan 10 gingerol dimana 6 gingerol dengan kandungan tertinggi dibandingkan dengan 8 dan 10 gingerol. Jahe emprit mempunyai gingerol lebih tinggi dari jahe merah pada penambahan $10 \%, 20 \%$, dan $30 \%$. Gingerol merupakan golongan fenol yang bersifat sebagai desinfektan yang paling umum yang digunakan di laboratorium sebagai penghambat pertumbuhan kuman atau membunuhnya. Kandungan gingerol dalam minyak jahe sekitar 20 sampai 30\% berat jahe (Putri, 2011).

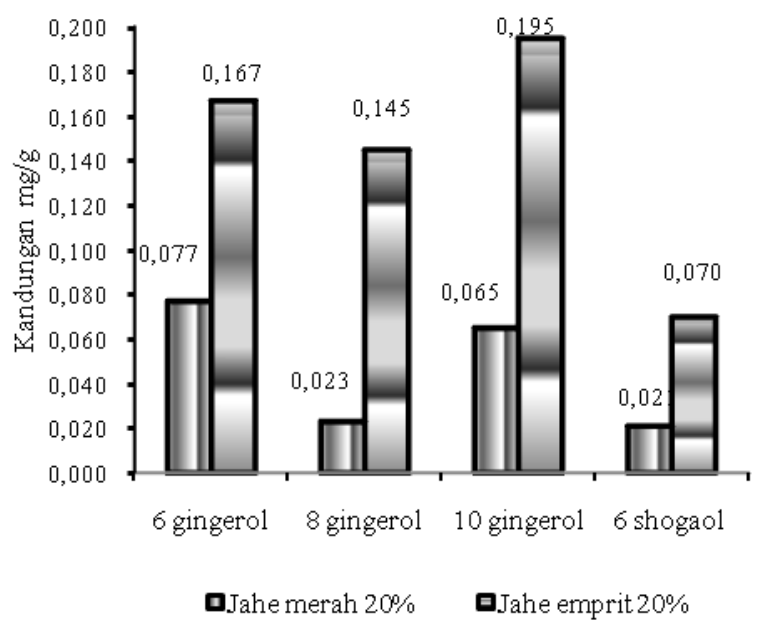

Gambar 2. Kadar Gingerol (6, 8, 10 gingerol) dan 6 Shogaol ting-ting jahe pada penambahan jahe $20 \%$.

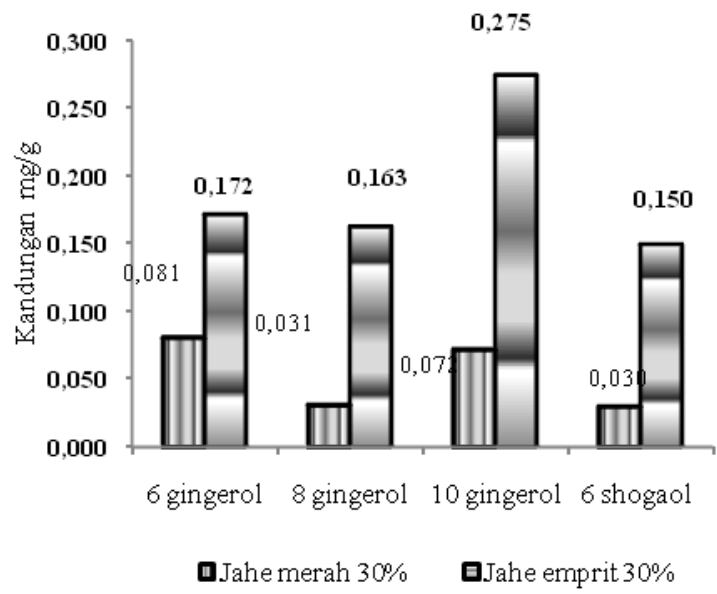

Gambar 3. Kadar Gingerol (6, 8, 10 gingerol) dan 6 Shogaol ting-ting jahe pada penambahan jahe $30 \%$.

Peningkatan persentase penambahan jahe seiring dengan peningkatan gingerol, dimana semakin bertambahnya persentase jahe maka meningkat pula kandungan gingerol $(6,8$, dan 10 gingerol). Penambahan jahe $30 \%$ dengan kandungan 6 gingerol $0,172 \mathrm{mg} / \mathrm{g}$ untuk jahe emprit dan $0,081 \mathrm{mg} / \mathrm{g}$ pada jahe merah.

Shogaol memiliki aroma yang lebih tajam dibandingkan dengan gingerol. Shogaol ditemukan pada jahe kering, berguna untuk mencegah oksidasi dari minyak dan lemak (Chrubasik et al., 2005). Ting-ting jahe dengan perlakuan penambahan jahe emprit mempunyai shogaol lebih tinggi dari jahe merah. Pada perlakuan penambahan jahe $10 \%$ menghasilkan shogaol pada jahe emprit $0,020 \mathrm{mg} / \mathrm{g}$ dan jahe merah 0,012 $\mathrm{mg} / \mathrm{g}$, begitu juga dengan penambahan $20 \%$ dan $30 \%$. Gingerol merupakan senyawa yang labil terhadap panas baik selama penyimpanan maupun pada waktu pemrosesan, sehingga gingerol sulit untuk dimurnikan, dan akan berubah menjadi shogaol (Zick et al., 2008). 


\subsection{Uji hedonik (rasa, aroma, dan tekstur)}

Uji hedonik dilakukan dengan metode skala tingkat kesukaan dengan kategori ( $1=$ tidak suka, $2=$ kurang suka, 3= biasa, 4= lebih suka, 5= sangat suka) dimana panelis memberikan penilaian terhadap ting-ting jahe terhadap rasa, aroma dan tekstur (Tabel 3).

Tabel 3

Hasil pengamatan nilai rata-rata ting-ting jahe pada pemakaian jahe emprit dan jahe merah terhadap rasa, aroma dan tekstur.

\begin{tabular}{llll}
\hline Perlakuan & Rasa & Aroma & tekstur \\
\hline Jahe emprit 10\% & 3,45 & 3,25 & 3,65 \\
Jahe emprit 20\% & 3,35 & 3,20 & 3,70 \\
Jahe emprit 30\% & 3,65 & 3,20 & 3,60 \\
Jahe merah 10\% & 3,50 & 3,45 & 3,70 \\
Jahe merah 20\% & 3,90 & 3,75 & 3,45 \\
Jahe merah 30\% & 3,75 & 3,80 & 3,65 \\
\hline
\end{tabular}

Penilaian terhadap rasa ting-ting jahe oleh panelis berkaitan dengan sifat khas jahe yang memberikan rasa hangat dan pedas jahe. Penilaian dengan nilai 1 sampai 5 (tidak suka - sangat suka) mendapatkan bahwa rasa tingting jahe disukai oleh semua panelis dengan nilai $(3,35$ - 3,90). Pemakaian jahe merah $20 \%$ dengan nilai ratarata rasa yang tertinggi yaitu 3,90 (disukai) diantara perlakuan lainnya. Rasa pedas jahe emprit lebih tajam dari jahe gajah dan jahe merah (El-Ghorab et al., 2010). Rasa jahe yang khas berupa rasa pedas dan hangat dikenal dengan pungent berasal dari sifat kimia jahe (gingerol, shogaol, dan zingeron), dua komponen utama yang memberikan pungent (rasa pedas) jahe adalah gingerol dan shogaol (Srinivasan, 2017).

Persentase penambahan jahe berpengaruh tidak nyata terhadap tingkat kesukaan panelis. Panelis lebih menyukai penambahan $30 \%$ untuk jahe emprit dengan nilai 3,65 dan $20 \%$ untuk jahe merah dengan nilai 3,90 (disukai). Menurut sebagian panelis, ting-ting dengan jahe emprit memberikan rasa pedas yang kuat dan aftertaste pahit pada awal konsumsi, sedangkan jahe merah rasanya pedas, dan memberikan rasa hangat di tenggorokan terasa spicy. Proses pemanasan dan pengadukan dapat mengurangi kepedasan jahe pada tingting jahe. Proses pengolahan jahe dapat mengubah homolog-homolog gingerol (6) gingerol menjadi shogaol yang memiliki ke pungent lebih rendah (Ghasemzadeh et al., 2010).

Hasil penilaian terhadap aroma ting-ting jahe disukai dengan nilai $(3,25-3,80)$ pada perlakuan penambahan jahe emprit dan jahe merah. Aroma ting-ting jahe adalah wangi khas jahe. Aroma jahe yang khas, menarik dan dapat meningkatkan selera makan. Penggunaan jahe merah pada ting-ting jahe lebih disukai aromanya dibandingkan dengan jahe emprit. Jahe emprit $30 \%$ mempunyai skor yang terendah dibanding dengan perlakuan lainnya. Aroma pangan berperan penting dalam menentukan daya terima konsumen. Penilaian aroma dilakukan oleh indera pembau. Pembauan disebut juga pencicipan jarak jauh karena seseorang dapat mengetahui enak tidaknya makanan yang belum terlihat.

Hasil uji organoleptik terhadap tekstur ting-ting jahe dengan perlakuan jahe emprit dan jahe merah seperti pada Tabel 3. Tekstur merupakan sekelompok sifat fisik yang ditimbulkan oleh elemen struktural bahan pangan yang dapat dilihat dirasa dan diraba. Tekstur atau penampakan dapat menarik konsumen sehingga tertarik untuk melihat dan mengkonsumsi produk tersebut. Tingting jahe mempunyai tekstur yang renyah, permukaan mengkilat dan warna yang menarik. Tekstur ting-ting jahe disukai panelis dengan nilai skor 3,42 - 3,70 (suka - sangat suka).

Tekstur merupakan daya tarik konsumen terhadap yang dilihat dan dirasakan. Tekstur ting-ting jahe renyah dengan permukaan mengkilat, hal ini karena ting-ting jahe dibuat dengan penambahan gula yang dipanaskan sehingga membentuk karamel kemudian gula membeku kembali, warna ting-ting kecoklatan sampai coklat. Karamelisasi juga menimbulkan aroma yang harum. Penambahan wijen meningkatkan nilai tekstur ting-ting jahe. Pengolahan yang kurang tepat akan menimbulkan tekstur dan warna yang tidak disukai. Pada penelitian ini tekstur yang paling disukai pada pemakaian jahe merah sebanyak 10\% dengan nilai 3,79 (disukai) dan secara keseluruhan perlakuan jahe merah dan jahe emprit pada penambahan $10 \%$, 20\%, dan 30\% jahe disukai panelis.

\section{Kesimpulan}

Ting -ting jahe merupakan produk olahan jahe yang mempunyai nilai komersial. Pemakaian jahe emprit dan jahe merah memberikan kadar air, total fenol, gingerol (6, 8, dan 10 gingerol) dan 6 shogaol yang berbeda, dimana jahe merah lebih disukai terhadap organoleptik rasa, aroma, dan tekstur. Peningkatan penambahan jahe pada $10 \%$, 20\%, dan $30 \%$ memberikan kandungan gingerol dan shogaol yang meningkat pula seiring dengan peningkatan penambahan jahe. Kadar air tingting jahe merah 1,24\% lebih rendah dari jahe emprit. Ting-ting dengan jahe emprit $30 \%$ merupakan perlakuan optimal dengan total fenol $1,66 \%$, gingerol $(6,8,10$ gingerol) berturut turut $0,172 \mathrm{mg} / \mathrm{g} ; 0,163 \mathrm{mg} / \mathrm{g} ; 0,275$ $\mathrm{mg} / \mathrm{g}$, dan 6 shogaol $0,150 \mathrm{mg} / \mathrm{g}$. Ting-ting jahe berpotensi untuk dikembangkan sebagai komoditi yang bernilai jual, memiliki penilaian organoleptik rasa, aroma dan tekstur 3,$90 ; 3,75 ; 3,45$ dengan nilai tertinggi pada perlakuan jahe merah $20 \%$.

\section{Ucapan terima kasih}

Terima kasih disampaikan kepada Bapak Robby Kumar dan Elya Rovina yang telah bekerjasama dan membantu kegiatan penelitian ini sehingga dapat berjalan dengan baik dan lancar .

\section{Daftar pustaka}

Asimi, O.A., Sahu, N.P., Pal, A.K., 2013. Antioxidant activity and antimicrobial property of some Indian spices. Int. J. Sci. Res. Publ. 3, 2250-3153.

Chrubasik, S., M.H.Pitler, Roufogalis, B.D., 2005. Zingiberis rhizome:Comprehensive review on the ginger effect and efficacy profiles. Phytomedine, Int. J. Phyther. Phytopharm. 12, 684-701.

Dugasani, S., Pichika, M.R., Nadarajah, V.D., Balijepalli, M.K., Tandra, S., Korlakunta, J.N., 2010. 
Comparative antioxidant and anti-inflammatory effects of [6]-gingerol, [8]-gingerol, [10]-gingerol and [6]-shogaol. J. Ethnopharmacol. 127, 515-520. https://doi.org/10.1016/j.jep. 2009.10.004

El-Ghorab, A.H., Nauman, M., Anjum, F.M., Hussain, S., Nadeem, M., 2010. A Comparative study on chemical composition and antioxidant activity of ginger (Zingiber officinale) and cumin (Cuminum cyminum). J. Agric. Food Chem. 58, 8231-8237. https://doi.org/10.1021/jf101202x

Erniati, E., Zakaria, F.R., Prangdimurti, E., Adawiyah, D.R., 2016. Potensi rumput laut: Kajian komponen bioaktif dan pemanfaatannya sebagai pangan fungsional. Acta Aquat. Aquat. Sci. J. 3, 12. https://doi.org/10.29103/aa.v3i1.332

Firdausni, F., Diza, Y.H., Failisnur, F., 2011. Potensi pigmen cassiavera pada minuman jahe instan sebagai minuman fungsional. J. Litbang Ind. 1, 15-21. https://doi.org/http://dx.doi.org/10.24960/jli.v1i1. 590.15-21

Firdausni, F., Hermianti, W., Kumar, R., 2017. Pengaruh penggunaan sukrosa dan penstabil karboksi metil selulosa (CMC) terhadap mutu dan gingerol jahe instan. J. Litbang Ind. 7, 137-146. https://doi.org/ 10.24960/JLI.V7I2.3364.137-146

Ghasemzadeh, A., Jaafar, H.Z.E., Rahmat, A., 2010. Antioxidant activities, total phenolics and flavonoids content in two varieties of malaysia young ginger (Zingiber officinale Roscoe). Molecules 15, 43244333. https://doi.org/10.3390/ molecules15064324.

Mukhtar, H., Ahmad, N., 2000. Tea polyphenols: prevention of cancer and optimizing health. Am. J. Clin. Nutr. 71, 1698S-702S; discussion 1703S-4S.
Pambayun, R., Gardjito, M., Sudarmadji, S., Kuswanto, K.R., 2007. Kandungan fenol dan sifat antibakteri dari berbagai jenis ekstrak produk gambir (Uncaria gambir Roxb). Maj. Farm. Indones. 18, 141-146.

Putri, I.S.I., 2011. Pengaruh penambahan ekstrak jahe (Zingiber officinale Roscoe) terhadap aktivitas antioksidan, total fenol dan karakteristik sensoris pada telur asin. Univ. Sebel. Maret.

Srinivasan, K., 2017. Ginger rhizomes (Zingiber officinale): A spice with multiple health beneficial potentials. PharmaNutrition. https://doi.org/ 10.1016/ j.phanu.2017.01.001

Stoilova, I., Krastanov, A., Stoyanova, A., Denev, P., Gargova, S., 2007a. Antioxidant activity of a ginger extract (Zingiber officinale). Food Chem. 102, 764 770. https://doi.org/10.1016/j.foodchem. 2006.06.023

Stoilova, I., Krastanov, A., Stoyanova, A., Denev, P., Gargova, S., 2007b. Antioxidant activity of a ginger extract (Zingiber officinale). Food Chem. 102, 764 770. https://doi.org/10.1016/j.foodchem.2006. 06.023

Yeh, H. yu, Chuang, C. hung, Chen, H. chun, Wan, C. jen, Chen, T. liang, Lin, L. yun, 2014. Bioactive components analysis of two various gingers (Zingiber officinale Roscoe) and antioxidant effect of ginger extracts. LWT - Food Sci. Technol. 55, 329334. https://doi.org/10.1016/j.lwt.2013.08.003

Zick, S.M., Djuric, Z., Ruffin, M.T., Litzinger, A.J., Normolle, D.P., Alrawi, S., Feng, M.R., Brenner, D.E., 2008. Pharmacokinetics of 6-gingerol, 8gingerol, 10-gingerol, and 6-shogaol and conjugate metabolites in healthyhuman subjects. Cancer Epidemiol. Biomarkers Prev. 17, 1930-1936. https://doi.org/10.1158/1055-9965.EPI-07-2934 